\section{Flat Earths and Fake Footnotes}

\author{
Derrick Peterson \\ in Flat Earths and Fake footnotes
}

https://doi.org/10.54739/h81w
In fourteen hundred and ninety-two,

Columbus sailed the ocean blue.

He took three ships with him, too,

And called aboard his faithful crew.

Mighty, strong and brave was he

As he sailed across the open sea.

Some people still thought the world was flat!

Can you even image that?

-A traditional children's poem

M

ost of us will remember quite vividly the first representation of Christopher Columbus that we were taught; like the glimmering icons of the Orthodox Church, his portrait was given to us less a man, and more an ideal. He was a thin veil through which a portentous light of Enlightenment found quite early access to key into the world. Against the stubbornness of a backwards society, Columbus was a man, so it was said, singularly convinced of the world's rotundity, and to settle this geometric bet he set sail. Behind his lambent form was the pitch abyss of a thousand years of medievalism, ignorant or deceived by the priests' wooden reading of "the four corners of the world" in scripture. It was from this morass that Columbus strode forward resolute, now tinged with the sort of heroic loneliness American mythology devours. "If no one ever challenged the status quo, the earth would still be flat" as a 2013 Infiniti car commercial put it-making it sound like Columbus literally remolded the earth into a sphere, despite popular taste preferring to take their planets flat, thank you very much. It was a breathtaking tale; both because of his resolution in the face of such apparently astounding religious ignorance, and because no doubt at least a few of our young minds fascinated upon the uncanny image of a horizon line of waters churning over that last, vital edge.

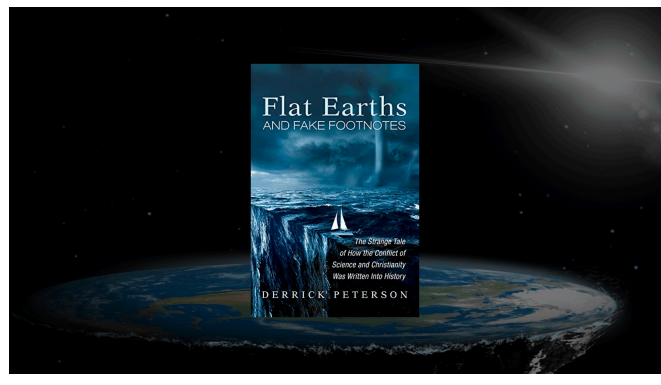

Nor was this some idiosyncrasy of our educations. The flat earth has been a convenient staple invoked in order to emphasize how humanity has advanced out of an age of superstition and religious ignorance for a while now. The historian of science Lawrence Principe records that over the course of a decade nearly $70 \%$ of his students-mainly American-were taught in grade school that Columbus set sail to prove the world was round. ${ }^{1}$ Another

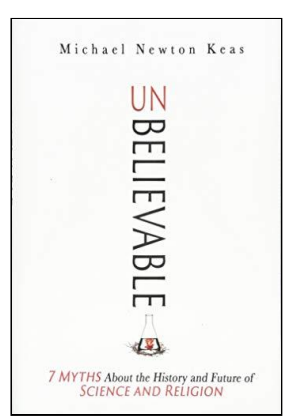
historian, Michael Newton Keas, notes that for the last quarter century he has taught around 1200 American students, a majority of whom by show of hands believed that medieval were ignorant regarding the roundness of the earth until Columbus. ${ }^{2}$ While he admits his method is anecdotal, broader evidence would suggest that his experience is, sadly, statistically typical. A best-selling history of science text mentions the flat earth in order to demonstrate how curiosity about the natural world was replaced by fear and bizarre superstition in the middle ages. A main culprit in this debacle of the human spirit was the Church, who "redirected the worries of 'educated' people toward abstract theological questions," so that knowledge of nature "was considered superfluous and dangerous." The condition of astronomical knowledge regressed from that established by the Greeks for seven hundred years, and "the Earth was once again considered to be flat!"3 This observation regarding the flat earth as symbolic of the general decline of knowledge caused by Christians is emblematic of its broader use. The Church set science back centuries, writes Timothy Ferris, and "the proud earth was hammered flat; likewise shimmering in the sun" while the heavens were wheels, pushed by angels in the courses of their perihelion. ${ }^{4}$ A Newsweek article for example conflated the flat earth with the Galileo affair (a confusion that no less prestigious an individual than Thomas Jefferson also committed to print) and baldly states that "the Catholic Church condemned Galileo in 1632 for his heretical notion that the earth was a round globe hurtling through space about the sun."

Well, no. Yet the article brazenly continues its questionable understanding of history by announcing that this backwardness was soon to crack as the age of exploration arose, and the Church's efforts to keep something they term "the traditional Ptolemaic flat-earth

\footnotetext{
1. Principe, “Transmuting History," 779-87. Figure at 786.

2. Keas, Unbelievable, 42-43.

3. Gleiser, The Dancing Universe, 59.

4. Ferris, Coming of Age in the Milky Way, 45.
} 
system" would be in vain. The Ptolemaic system held no such flat earth view, of course, but it certainly sounds good if no further questions are asked. Unfortunately Christians themselves have imbibed these claims, and as David Kinnamin and Gabe Lyons reported in their book Unchristian: What a New Generation Really Thinks About Christianity the activities of a church listing five things Christians needed to apologize for-“We're Sorry For Saying the Earth Is Flat," being among them. ${ }^{5}$ Of all the things Christians should actually apologize for, this one is both entirely wrong and-even if true-seems fairly superfluous given other atrocities supposedly done in Christ's name. It does go to show in an exemplary way, however, how the power of myth can affect even the groups who should be the least inclined to believe them.

Nonetheless, in the name of fairness, it is hard to expect many to know much different when this sort of thing has been part of education for a long while. A widely distributed textbook for middle schoolers, for example, notes that: "Many Europeans still believed the world was flat. Columbus, they thought, would fall off the earth." And a popular fifth-grade text from around the same time repeats this nearly verbatim: "The European sailor ... believed ... that a ship could sail out to sea just so far before it fell off the edge ..."7 It is very hard to fault people, therefore, for retaining their education! As Christine Garwood puts it, "as children across America chewed their pencils and stared out of ... windows, two conjoined 'facts' were absorbed: medieval people believed the earth to be flat, [and second, that] Columbus was the first to prove it was a globe." 8 This was certainly how it has been presented in popular media as well:
Columbus: The earth is not flat, father, it is round!
Roman Catholic Priest: Don't say that!
Columbus: It's the truth; it's not a mill-pond strewn with islands, it's a sphere.
Roman Catholic Priest: Don't, don't say that; it's blasphemy! ${ }^{9}$

It is no coincidence that the way this scenario is depicted mirrors precisely how depictions of the Galileo affair has been passed down in popular lore. Yet, the actual history is quite different. As Jeffrey Burton Russell puts it in his book-length study on the myth of the flat earth: "in reality, there were no skeptics [of a round earth]. All educated people throughout Europe knew the earth's spherical shape and its approximate circumference. ${ }^{10}$ C.S. Lewis (who, we sometimes forget because of his popular fiction and apologetic works, had an actual day-job holding the Chair of Medieval and Renaissance Literature at Cambridge) wrote in his survey of the Medieval period: "Physically considered, the earth is a globe; all the authors of the High Middle Ages are agreed on this. ... The implications of a spherical earth were fully grasped." ${ }^{11}$ The list of who knew this is so vast as to constitute essentially every educated person for the last two and a half millennia: Aristotle, Plato, The

5. Kinnamin and Lyons, Unchristian, 55-56.

6. Bidna, We The People, 28-29.

7. Schreiber, America Past and Present, 98.

8. Garwood, Flat Earth, 2.

9. Quoted in Grant, God and Reason in the Middle Ages, 345. Though it will become quite evident later, it should be noted Grant is here debunking the myth, not supporting it.

10. Russell, Inventing the Flat Earth, 2.

11. Lewis, The Discarded Image, 140-41.
Venerable Bede, St. Augustine, St. Thomas Aquinas, and on and on. ${ }^{12}$ "We can state categorically," says British historian of science James Hannam, "that the flat earth was at no time ever an element of Christian doctrine, and that no one was ever persecuted or pressured into believing it."13

$T$ o be sure, many of humanity's earliest commentators reasoned back and forth regarding the ultimate shape of the ground we awoke upon as a species. The

Sumerians and Babylonians claimed that beneath the sky, but above the underworld, the earth stretched like a flat plane or disk, interrupted only by mountains and seas. ${ }^{14}$ Many have argued that Thales of Melitus (c.625-c.547 B.C.), the Ionian geometer and natural philosopher, whom Aristotle records as being something of an original thinker, ${ }^{15}$ and who is often credited with being the first philosopher of the West, believed the earth was a circular disk, like a piece of wood afloat a vast and shoreless sea. "This opinion," writes Aristotle, "is the most ancient which has come down to us, and is attributed to Thales." ${ }^{16}$ This may have come from descriptions made by many like Herodotus, who in his Histories, describes a "floating island," Chemmis, north-east of Naucratis, an Egyptian trading post. ${ }^{17}$ On the other hand, Cicero attributed to Thales the earliest idea of a celestial globe. ${ }^{18}$ There is in fact an ambiguity in Aristotle, who may also be describing Thales as a "globalist" when he notes some have thought the earth is spherical. ${ }^{19}$ Regardless, Aristotle does ascribe a flat-earth view to Anaximenes, Anaxagoras, and Democritus. ${ }^{20}$

By and large the round earth was the position taken by the Greeks, however. Accordingly, it is sometimes argued on the basis of Christian maps that the Greek view of the round earth was lost-even suppressed-by the rise of Christianity. A 1988 textbook, for example, reads:

The maps of Ptolemy ... were forgotten in the West for a thousand years, and replaced by imaginary constructions based on supposed teachings of Holy Writ. The sphericity of the earth was, in fact, formally denied by the church, and the mind of the Western man, so far as it moved in this matter at all, moved back to the odd confused notion of a modulated 'flatland' with the kingdoms of the world surrounded by Jerusalem, the divinely chosen centre of the terrestrial disk. ${ }^{21}$

12. Regarding the globular view of earth in Plato's Phaedo and why, despite a few ambiguities, Plato most certainly did believe in a round earth, see: Calder III, "The Spherical Earth in Plato's Phaedo," 121-25; Augustine, De Genesi Ad Litteram, 1:9-10; 1:19; 1:21; 2:9; Bede, De Natura Rerum ch. 3, 5, 6-10; Aquinas, Summa Theologia, Ia.q.68.a2.

13. Hannam, Genesis of Science, 28.

1W.alton, Ancient Near Eastern Thought and The Old Testament, 172.

1\$ristotle, Metaphysica, 983 b20-28.

1Aristotle, De Caelo 294 a28-30.

17erodotus, The Histories, II.156.

18icero, Republic I.XIII.22.

1Aristotle, De Caelo, 293 b33-294 a1.

2Aristotle, De Caelo, 294 b14-15.

21. Holt-Jenson, Geography: Its History and Concepts, 12-13. 
And in 1986, William O'Neil could still write of the Church Fathers that:

\begin{abstract}
Without differentiating amongst the details of their several views it may be said that they rejected the Hellenistic notion of the sphericity of the earth and of the universe in favor of a layered, flat, square scheme as suggested by Genesis. Indeed to varying degrees they tended to support the view that the Mosaic Tabernacle represented the shape of the universe. ${ }^{22}$
\end{abstract}

Yet this is utterly false. The Venerable Bede (A.D. 672-735), the famous scholar and monk at the monastery of St. Peter in Northumbria, later takes up a similar argument in his work On Times (Bedae opera de temporibus):

\begin{abstract}
The cause of the inequality of the length of days is that the earth is round, and it is not in vain that in both the bible and pagan literature it is called 'orb of lands.' For truly it is an orb placed in the center of the universe; in its width it is like a circle, and not circular like a shield but rather like a ball, and it extends from its center with a perfect roundness on all sides. ${ }^{23}$
\end{abstract}

Here we are left with little doubt, for Bede spends the time to speak of the difference between the words "ball" and "plate" with the earth being the former. For other arguments regarding the spherical earth, in the Western tradition, we can take Aristotle (384-322 B.C.) as typical of thinking on the matter in his work de Caelo [On The Heavens]:

[T]he evidence of the senses further corroborates [a spherical earth]. How else would eclipses of the moon show segments shaped as we see them? As it is, the shapes which the moon itself each month shows are of every kind-straight, gibbous, and concave-but in eclipses the outline is always curved; and since it is the interposition of the earth that makes the eclipse, the form of this line will be cased by the form of the earth's surface, which is therefore spherical. Again, our observation of the stars makes it quite evident, not only that the earth is circular, but also that it is a circle of no great size. For quite a small change of position on our part to south or north causes a manifest alteration of the horizon. ... All of which goes to show not only that the earth is circular in shape, but also that it is a sphere of no great size; for otherwise the effect of so slight a change of place would not be so quickly apparent. ... ${ }^{24}$

Others like Eratosthenes (c.276-c.194 B.C.), a Libyan astronomer and Librarian of Alexandria, used mathematical reasoning to prod from the Earth the secret of its waistline. Utilizing "trigonometry obtained from observations of the sun's declination at different latitudes," 25 Eratosthenes devised an ingenious method to calculate the world's shape and size. He heard reports from a town called Syene that during the summer solstice, the sun cast no shadow because it was directly overhead.

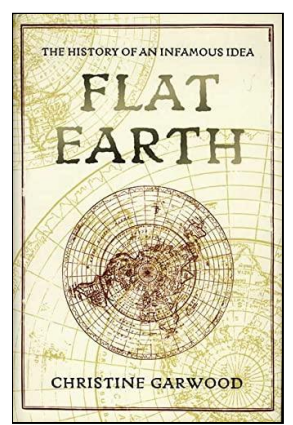

22. Quoted in Russell, Inventing the Flat Earth, 47.

23. Text taken from Russell, Inventing the Flat Earth, 87n.55.

24. Aristotle, De Caelo, 2.14, 297b-298a.20.

25. Russell, Inventing the Flat Earth, 25.
At the same time in Eratosthenes' home city of Alexandria, Egypt, the sun still cast a shadow at an angle equivalent to one-fiftieth of a circle (or seven point two degrees). Assuming the sun's rays are basically parallel, and that Alexandria was approximately (what we would measure as) five-hundred and thirty miles due north of Syene, the calculation based on the radius of a circle could be made to estimate that the circumference of the earth was in the ballpark of twenty-nine thousand miles. We do not know the exact figure, since Eratosthenes was working with "stadia" as a unit of measurement-the earth, he said, being about 250,000 of them-and no one is completely certain what precisely this length indicates. The problem being that "Stadia" literally indicates "the length of one Roman stadium," which runs into the immediate problem that stadiums had no real set length. Regardless, from a shadow in a well, this is a pretty imaginative method to say the least, and one that is not too far off from the length we now know to be a circumference of around 24,860 miles. $^{26}$

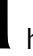
his amazing feat of geometry turns out to be an important bit of trivia for how Columbus' arguments with the Spanish court and the scholastics at Salamanca actually went. Several estimates of the circumference of the world-including Eratosthenes'-had been passed down, many of which were much larger. Dazzled by the travel narratives of Marco Polo and Pierre d'Ailly, Columbus was hellbent upon making the journey, and so through either sincere belief or a bit of sleight of hand Columbus not only picked the smallest available number, but ended up reducing that again by something along the lines of twenty-percent. Many were not convinced by Columbus' miniaturization. The highest irony is that not only was the flat earth not an issue raised, the opponents of Columbus held to a round earth so implicitly it was one of the major premises in their arguments against the viability of his proposed journey! Aristotle had estimated that the spherical world was around 400,000 stadia, nearly twice the size that Eratosthenes had calculated, for example. As such, because the world was round the physical implications of this were thought by many to indicate that it was simple too enormous for Columbus to successfully execute his journey without starving everyone on board. Though there are no records of that exchange, we do have accounts written by Fernando, Columbus' son, and by Bartolomé de las Casas:

... the replies and reports that the geographers gave their Highnesses were as varied as their grasp of the subject and their opinions. ... [Some] who based themselves on geography, claimed the world was so large that to reach the end of Asia, whither the Admiral wished to sail, would take more than three years ... To this they added that of this inferior sphere of land and water only a small belt or cap was inhabited, all the rest being sea that could be navigated only near coasts and shores. And even if learned men admitted that one could reach the end of Asia, they did not say that one could go from the end of Spain to the extreme West. Others argued ... that if one were to set out and travel due west, as the Admiral proposed, one would not be able to return to Spain because the world was round [emphasis added]. These men were absolutely certain that one who left the hemisphere known to Ptolemy would be going downhill and so could not return, for that would be like sailing a ship to the top of a mountain, a thing that ships could not do even with the aid of the strongest wind. ${ }^{27}$ 
Now admittedly, that last bit about getting stuck at the bottom of the world will no doubt bring a smile to the reader's face for being so quaint. But we will do well to remember that they were following well entrenched principles of Ptolemaic science, and it is hard to blame this subset of men arguing such things for not being up to date on gravity or the relativity of motion nearly two centuries in advance of Isaac Newton and four before Einstein. For the Ptolemaic layout, up was up, and down was down. Hence the notion that moving along the circulature of the earth's sphere would bring with it as one traveled a shift in the frame of

27. Colon, The Life of the Admiral Christopher Columbus by His Son Ferdinand, 39.

\section{References}

Principe, Lawrence M. “Transmuting History.” Isis 98 no.4 (2007): 779-87.

Keas, Michael Newton. Unbelievable: 7 Myths About the History and Future of Science and Religion. (Delaware: ISI Books, 2019).

Gleiser, Marcelo. The Dancing Universe: From Creation Myths to the Big Bang (New York: Plume, 1998).

Ferris, Timothy. Coming of Age in the Milky Way (New York: William Morrow \& Co, 1988).

Kinnamin, David and Lyons, Gabe. unChristian: What a New Generation Really Thinks about Christianity ... and Why It Matters (Ada: Baker Books, 2007).

Bidna, David B. We the People: A History of the United States (Lexington: D.C. Heath and Company, 1977).

Schreiber, Joan E. America Past and Present (Northbrook: Scott Foresman, 1986).

Garwood, Christine. Flat Earth: The History of an Infamous Idea (New York: Thomas Dunne, 2007).

Grant, Edward. God \& Reason in the Middle Ages (Cambridge: Cambridge University Press, 2001).

Russell, Jeffrey Burton. Inventing the Flat Earth: Columbus and Modern Historians. (Connecticut: Prager Publishers, 1997). reference did not occur to them. Columbus was not immune to this opinion. In his travel journals transcribed by de las Casas, Columbus remarks that as he entered the mouth of the Orinoco river the vast pressures against the boat led him to believe he may have already run into the hill of the earth's curvature, and was beginning to sail upward. Far from invoking fear, however, a thrill came over Columbus in part because of the idea put forward by the theologian Peter Lombard, and later by the poet Dante, speculating that the earth was in fact more shaped like a pear hanging from a tree-with the lost paradise of Eden sitting atop the bulging crest of the world. The thought of trying to storm Eden, inaccessible because of the currents stemming from the cataract of waters glissading downward off the roof of the world was no small motivator for Columbus to continue forward, whatever the cost.

Lewis, C.S. The Discarded Image: An Introduction to Medieval and Renaissance Literature. (Cambridge: Cambridge University Press, 2012).

Calder III, William M. “The Spherical Earth in Plato's Phaedo.” Phronesis 3 no2. (1958):121-125.

Augustine. De Genesi Ad Litteram. 1:9-10; 1:19; 1:21; $2: 9$.

Bede. De Natura Rerum. ch. 3, 5, 6-10

Aquinas, Thomas. Summa Theologia. Ia.q.68.a2.

Hannam, James. The Genesis of Science: How the Christian Middle Ages Launched the Scientific Revolution (Washington, D.C.: Regnery Publishing, 2011).

Walton, John H. Ancient Near Eastern Thought and The Old Testament (Ada: Baker Academic, 2006).

Aristotle. Metaphysica. 983 b20-28.

Aristotle. De Caelo. 293 b33-294 a1; 294 a28-30; 294 b14-15.

Herodotus. The Histories. II.156.

Cicero, Marcus Tullius. Republic. I.XIII.22.

Holt-Jenson, A. Geography: Its History and Concepts - A Student's Guide, 2nd Ed. (London, 1988).

Colon, Fernando. The Life of the Admiral Christopher Columbus by His Son Ferdinand (New Brunswick: Rutgers University Press, 1959). 